\title{
Análise dialélica para resistência a ferrugem polissora em milho em diferentes níveis de adubação fosfatada
}

\author{
Gustavo André Colombo (*); Aurélio Vaz-de-Melo; Markus Taubinger; Rodrigo de Castro Tavares; \\ Rubens Ribeiro da Silva \\ Universidade Federal do Tocantins (UFT), Programa de Pós-graduação em Produção Vegetal, Caixa Postal 66, $77402-970$ Gurupi \\ (TO) Brasil. \\ $\left({ }^{*}\right)$ Autor correspondente: colombo@uft.edu.br
}

Recebido: 31/jan./2013; Aceito: 2/fev./2014

\begin{abstract}
Resumo
A avaliação de germoplasmas como ferramenta na busca de genes que confiram resistência a doenças na cultura do milho tem sido meta constante em programas de melhoramento. Com esse intuito, determinou-se, por meio de cruzamento dialélicos, a capacidade geral (CGC) e específica (CEC) de combinação para resistência a Puccinia polysora de oito híbridos comerciais de milho em diferentes níveis de adubação fosfatada. Cultivaram-se 56 combinações híbridas (F1s e recíprocos) e oito genitores em dois ambientes distintos quanto à disponibilidade de fósforo (baixo e alto P) e avaliou-se a severidade de ataque da ferrugem polissora, de acordo com a área abaixo da curva de progresso da doença (AACPD). A análise de variância conjunta indicou que os híbridos diferiram significativamente $(p<0,01)$ quanto à curva de progresso da ferrugem polissora, sinalizando a existência de variabilidade genética entre eles na resistência à incidência da doença. O maior valor do quadrado médio da CGC comparado a CEC evidenciou, nesses genitores, maior contribuição da ação gênica aditiva no controle da resistência à ferrugem polissora. As combinações híbridas recíprocas P30F53 x AG 8060 e TRUCK x BM 2202 apresentaram as maiores médias negativas de CEC, em ambientes de baixo e alto fósforo, respectivamente, e foram classificadas, assim, como promissoras para obtenção de resistência à ferrugem polissora.
\end{abstract}

Palavras-chave: zea mays, puccinia polysora, estresse biótico, melhoramento genético, resistência genética.

\section{Diallel analysis for resistance to southern rust in corn at different levels of phosphorus fertilization}

\section{Abstract}

The evaluation of germplasm as a tool in search of disease resistance genes in corn has been a constant target in breeding programs. With this end, it was determined through diallel crossing, the general (GCA) and specific combining ability (SCA) for resistance to Puccinia polyssora eight commercial corn hybrids at different levels of phosphorus fertilization. Were cultured 56 hybrid combinations (F1's and reciprocals) and eight parents in two different environments as the availability of phosphorus (low and high P), and evaluated the severity of disease attack, according to the area below the curve of disease progress. The analysis of variance indicated that the hybrids differed significantly $(p<0.01)$ regarding the progress curve polissora rust, indicating the existence of genetic variability among hybrids in resistance to disease incidence. The largest mean square of GCA compared to SCA showed, these parents, the greatest contribution of additive gene action in the control of rust resistance polissora. The reciprocal hybrids P30F53 x AG 8060 and TRUCK x BM 2202 showed the largest negative average SCA in environments of low and high phosphorus, respectively, classified as promising for obtaining polissora rust resistance.

Key words: zea mays, puccinia polysora, biotic stress, breeding, genetic resistance.

\section{INTRODUÇÃO}

Dentre as patologias conhecidas, a ferrugem polissora, cujo agente etiológico é o fungo Puccinia polysora, é atualmente uma das mais relevantes doenças do milho no Brasil. De acordo com Costa et al. (2012), essa ferrugem é tratada como a mais agressiva das que ocorrem na cultura, causando perdas de até $65 \%$ em lavouras com histórico de incidência da doença. Fatores como o monocultivo em sistema de plantio direto e o uso de híbridos suscetíveis associados à ocorrência de clima favorável à propagação dos inóculos têm contribuído para o aumento na ocorrência de ferrugem polissora em lavouras brasileira.

A utilização de híbridos resistentes aos patógenos é apontada como a mais eficiente e econômica ferramenta 
no manejo integrado de doenças na cultura do milho. Dessa forma, o desenvolvimento de linhagens resistentes a doenças foliares é um dos objetivos dos programas de melhoramento genético de milho (Silveira et al., 2006).

Diferentes estudos mostram a existência de grande variabilidade genética quanto à resistência à ferrugem polissora (Nihei e Ferreira, 2012; Vieira et al., 2011; Vivek et al., 2010). Essa resistência à ferrugem consiste na capacidade de a planta suprimir a taxa de desenvolvimento da doença, geralmente caracterizada por pequenas lesóes e menos esporulação. A área abaixo da curva de progresso da doença (AACPD), que quantifica a evolução da doença durante determinado período, é um critério comumente utilizado para avaliar o nível de resistência em condiçôes de campo (Vieira et al., 2011).

O sucesso de um programa de melhoramento na obtenção de híbridos superiores passa pela determinação dos parâmetros genéticos que governam a resistência, de modo a direcionar os trabalhos de introdução da característica em germoplasma suscetível. Segundo Guimarães et al. (2009), conhecer e explorar os efeitos aditivos e não aditivos de genes sobre a melhoria de populações e o desenvolvimento de linhagens é ponto crucial para escolha dos métodos de melhoramento a serem empregados na condução do programa, por possibilitar maiores ganhos de seleção.

Apesar de grande parte das características que conferem resistência a estresse em milho serem controladas por genes nucleares, há casos em que ela é herdada de genes presentes no citoplasma, cujas características não são transmitidas hereditariamente via pólen mas sim via gameta feminino (José et al., 2004). Desse modo, para estudar esse tipo de herança, recomenda-se verificar se há diferença entre os resultados de um cruzamento e os de seu recíproco.

Uma das metodologias mais eficientes no estudo genético em programas de melhoramento genético é a análise dialélica (Cruz et al., 2012). O método proposto por Griffing (1956), que fornece informaçôes quanto à capacidade geral (CGC) e à capacidade específica (CEC) de combinação dos genitores em cruzamentos artificiais, é amplamente utilizado em várias espécies cultivadas, promovendo o entendimento dos efeitos genéticos envolvidos na determinação dos caracteres, bem como possibilitando a identificação de combinaçôes híbridas de interesse agronômico (Engelsing et al., 2011).

Nesse contexto, objetivou-se com o presente trabalho quantificar os efeitos das capacidades geral (CGC) e específica (CEC) de combinação, bem como o efeito recíproco, associados à resistência à ferrugem polissora de oito híbridos comerciais de milho em função da área abaixo da curva de progresso da doença (AACPD), sob dois níveis de adubação fosfatada.

\section{MATERIAL E MÉTODOS}

O trabalho foi conduzido em solo classificado como Latossolo Vermelho-Amarelo distrófico, com a seguinte composição físico-química: $\mathrm{pH}$ em $\mathrm{H}_{2} \mathrm{O}=5,16$; M. $\mathrm{O}=4,43 \mathrm{~g} \mathrm{dm}^{-3}$; P $\left(\right.$ Melich $\left.^{-1}\right)=0,82 \mathrm{mg} \mathrm{dm}^{-3}$; $\mathrm{Ca}=0,82 \mathrm{cmol} \mathrm{dm}_{c}^{-3} ; \mathrm{Mg}=0,49 \mathrm{cmol}_{c} \mathrm{dm}^{-3} ; \mathrm{Al}=0,28 \mathrm{cmol}_{c}$ $\mathrm{dm}^{-3} ; \mathrm{H}+\mathrm{Al}=3,43 \mathrm{cmol}_{\mathrm{c}} \mathrm{dm}^{-3} ; \mathrm{K}=0,31 \mathrm{cmol} \mathrm{dm}_{c}^{-3} ; 66 \% \mathrm{de}$ areia; $7,5 \%$ de sílte e $26,5 \%$ de argila.

Foram utilizados como genitores oito híbridos de milho (Tabela 1), previamente avaliados em ambientes contrastantes quanto à fertilidade do solo, indicados ao cultivo nas condiçôes edafoclimáticas do Tocantins, de acordo com o zoneamento agroclimático do milho (BRASIL, 2013).

O bloco de cruzamentos foi conduzido na safra 2010/2011, em que foram realizados todos os cruzamentos possíveis entre os genitores para a formação de um dialelo completo, dando origem a 56 combinações híbridas.

$\mathrm{Na}$ safra 2011/2012 foi realizado experimento com as 56 combinações híbridas e os oito genitores, com intuito de avaliar a capacidade de combinaçáo dos híbridos de milho quanto à resistência à ferrugem polissora (Puccinia polysora). O delineamento experimental utilizado foi o látice $8 \times 8$, com duas repetiçóes. A parcela experimental foi constituída de duas linhas de quatro metros de comprimento espaçadas em 0,70 metro.

As combinações híbridas foram avaliadas em dois ambientes contrastantes quanto à dose de fósforo, descritos como alto $\mathrm{P}\left(170 \mathrm{~kg} \mathrm{ha}^{-1}\right.$ de $\left.\mathrm{P}\right)$ e baixo $\mathrm{P}\left(34 \mathrm{~kg} \mathrm{ha}^{-1} \mathrm{de} \mathrm{P}\right)$. Foi utilizado o sistema convencional de cultivo e realizada, ainda, a adubaçấo com $150 \mathrm{~kg} \mathrm{ha}^{-1}$ de N e $120 \mathrm{~kg} \mathrm{ha}^{-1}$ de $\mathrm{K}_{2} \mathrm{O}$ quando as plantas atingiram o estádio fenológico V4.

As avaliaçôes de severidade foram realizadas logo após o florescimento masculino (estádio R1), com intervalos

Tabela 1. Descrição dos híbridos comerciais de milho avaliados em relação a resistência à ferrugem polissora (Puccinia polysora), safra $2011 / 2012$

\begin{tabular}{|c|c|c|c|c|}
\hline Híbridos & Empresa & $\begin{array}{l}\text { Base } \\
\text { genética }\end{array}$ & $\begin{array}{c}\text { Nível } \\
\text { tecnológico }\end{array}$ & $\begin{array}{l}\text { Textura do } \\
\text { grão }\end{array}$ \\
\hline AG 2040 & $\begin{array}{l}\text { Monsanto/ } \\
\text { Agroceres }\end{array}$ & HD & Médio & SEMIDURO \\
\hline AG 8060 & $\begin{array}{l}\text { Monsanto/ } \\
\text { Agroceres }\end{array}$ & HS & Alto & DURO \\
\hline AG 1051 & $\begin{array}{l}\text { Monsanto/ } \\
\text { Agroceres }\end{array}$ & HD & Médio/Alto & DENTADO \\
\hline BM 2202 & $\begin{array}{l}\text { Sementes } \\
\text { Biomatrix }\end{array}$ & HD & Médio/Baixo & SEMIDENTADO \\
\hline P30F53 & $\begin{array}{l}\text { Pioneer } \\
\text { Sementes }\end{array}$ & HS & Alto & SEMIDURO \\
\hline P30F80 & $\begin{array}{l}\text { Pioneer } \\
\text { Sementes }\end{array}$ & HS & Alto & DURO \\
\hline TRUCK & $\begin{array}{l}\text { Syngenta } \\
\text { Seeds }\end{array}$ & $\mathrm{HT}$ & Médio & SEMIDURO \\
\hline IMPACTO & $\begin{array}{l}\text { Syngenta } \\
\text { Seeds }\end{array}$ & HS & Alto & DURO \\
\hline
\end{tabular}


de sete dias, totalizando seis avaliaçóes, sendo a última realizada aos 42 dias após o florescimento. Foram avaliadas dez plantas por parcela (ao acaso e no meio das linhas), em condiçóes naturais de infecção, por meio de uma escala de notas baseada na escala diagramática do Guia Agroceres de Sanidade (Agroceres, 1996): 1, 2, 3, 4, 5, 6, 7, 8 e 9, correspondente a: $0 \%, 1 \%, 10 \%, 20 \%, 30 \%, 40 \%, 60 \%$, $80 \%$ e $>80 \%$, respectivamente.

Durante as avaliaçóes dos híbridos foram realizadas coletas de folhas doentes para comprovação da doença. Posteriormente, em laboratório, as amostras foram colocadas em câmara úmida proporcionada por saco plástico contendo no seu interior os tecidos doentes e algodáo embebido em água estéril, visando o desenvolvimento das estruturas do patógeno. Após três dias de incubação, os tecidos foram visualizados em microscópio de luz, classificando-se o patógeno de acordo com as descriçôes de Ellis (1971).

O progresso da ferrugem polissora foi quantificado através do cálculo da área abaixo da curva de progresso da doença (AACPD), pela equação de Das (1992), a qual faz uma relação entre a severidade da doença e a evolução da doença no tempo:

$\mathrm{AACPD}=\sum\left[\left(\left(\mathrm{Y}_{i}+\mathrm{Y}_{i+1}\right) / 2\right) \times\left(\mathrm{T}_{i+1}-\mathrm{T}_{i}\right)\right]$

onde Y: percentagem de área foliar afetada pela ferrugem na $i$-ésima observação; $T_{:}$: tempo da avaliação $i$ em números de dias após a semeadura; $\mathrm{e}_{i+1}$ : tempo da avaliaçáo $i+1$.

A metodologia utilizada para estimar os efeitos de capacidade geral e especifica de combinaçáo foi a proposta por Griffing (1956) - método 1 -, utilizando progenitores, $\mathrm{F}_{1}$ s e recíprocos. Foram realizadas as análises dialélicas em cada ambiente, utilizando o modelo estatístico:

$Y_{i j}=m+g_{i}+g_{j}+s_{i j}+r_{i j}+\varepsilon_{i j}$

em que $Y_{\mathrm{ij}}$ : observação da combinaçáo híbrida envolvendo os genitores i e j; m: média geral; $\mathrm{g}_{\mathrm{i}}$ e $\mathrm{g}_{\mathrm{i}}$ : capacidade geral de combinação do i-ésimo e j-ésimo genitor, respectivamente; $s_{\mathrm{ij}}$ : capacidade específica de combinaçáo para os cruzamentos entre os genitores de ordem i e j; $\varepsilon_{\mathrm{ij}}$ : erro experimental médio; e $r_{i j}$ : efeito recíproco que mede as diferenças proporcionadas pelo progenitor i ou j, quando utilizado como macho ou fêmea no cruzamento ij. Nesse modelo são consideradas $s_{\mathrm{ij}}=s_{\mathrm{ji}}, \mathrm{r}_{\mathrm{ij}}=-\mathrm{r}_{\mathrm{ji}}$ e $\mathrm{r}_{\mathrm{ii}}=0$.

Todas as análises genéticas estatísticas foram realizadas utilizando-se o Aplicativo Computacional em Genética e Estatística - Programa Genes (Cruz, 2006).

\section{RESULTADOS E DISCUSSÃO}

A análise de variância conjunta indicou que os híbridos diferiram significativamente $(\mathrm{p}<0,01)$ quanto à curva de progresso da ferrugem polissora (Tabela 2). Esse resultado demonstra a existência de variabilidade genética entre os híbridos na resistência à incidência da doença. A análise revelou, ainda, que, os níveis de adubação fosfatada influenciaram significativamente $(\mathrm{p}<0,05)$ no progresso da ferrugem polissora sobre os híbridos. Contudo, não houve significância na interação entre híbridos e ambientes, inferindo-se que o estudo isolado dos níveis de resistência dos híbridos em relação aos dois níveis de adubação empregados foi suficiente para explicar todas as variaçóes encontradas, não sendo necessário realizarem-se, nesse caso, os desdobramentos.

Os coeficientes de variação oscilaram de $15,66 \%$ a $18,13 \%$, sendo o menor valor observado no ambiente de baixo fósforo. De acordo com Scapim et al. (1995), coeficientes de variação dessa magnitude nas avaliaçôes de doença são considerados aceitáveis para a cultura do milho (Tabela 1), ressaltando-se que os dados não foram transformados para redução do resíduo. Coeficientes de variação acima de 15\% podem estar ligados a uma desuniformidade da doença sobre as plantas nas parcelas, uma vez que a infecçáo do patógeno ocorreu de forma natural. Em trabalhos de avaliação de severidade de doenças em milho sobre estresse mineral, Vaz-de-Melo et al. (2010) e Carvalho et al. (2010), em avaliaçōes da severidade de doenças fúngicas sobre a cultura do milho, encontraram coeficientes de variação acima de $18 \%$, confirmando que os valores encontrados no presente trabalho encontram-se em magnitude aceitável nesse tipo de avaliaçấo.

Tabela 2. Resumo da análise de variância, individual e conjunta, entre oito híbridos comerciais de milho e suas 56 combinaçóes híbridas (F1s e recíprocos) para resistência à ferrugem polissora (Puccinia polysora) em funçáo da área abaixo da curva de progresso da doença (AACPD), em dois níveis de adubação fosfatada, em Gurupi, TO, safra 2011/2012

\begin{tabular}{lcc|}
\hline Fonte de variação & Grau de liberdade & Quadrado médio \\
\hline Repetições & \multicolumn{3}{c}{ Baixo P } \\
\hline BL/REP (AJ) & 14 & 104910,62 \\
\hline Híbridos & 63 & 8801,93 \\
\hline Erro efetivo & 49 & $5556,89^{\text {ns }}$ \\
\hline Média & 95,56 & 6701,56 \\
\hline CV & 15,66 & \\
\hline & & Alto P \\
\hline Repetições & 1 & \\
\hline BL/REP (AJ) & 14 & 8188,00 \\
\hline Híbridos & 63 & 8771,73 \\
\hline Erro efetivo & 49 & $9463,15^{* *}$ \\
\hline Média & 119,83 & 4852,77 \\
\hline CV & 18,13 & \\
\hline & & Conjunta \\
\hline Híbridos & 63 & $10040,84^{* *}$ \\
\hline Ambiente & 1 & $37690,58^{*}$ \\
\hline H $\times$ A & 63 & $4979,20^{\text {ns }}$ \\
\hline Erro & 98 & 5777,17 \\
\hline
\end{tabular}

ns, *, **: nâo significativo, significativo a $5 \%$ e significativo a $1 \%$ pelo teste $\mathrm{F}$, respectivamente; Baixo P: $34 \mathrm{~kg} \mathrm{ha}^{-1}$ de $\mathrm{P}_{2} \mathrm{O}_{5}$; Alto P: $170 \mathrm{~kg} \mathrm{ha}^{-1}$ de $\mathrm{P}_{2} \mathrm{O}_{5}$ 
$\mathrm{Na}$ análise dialélica conjunta (Tabela 3 ) foram constatados efeitos significativos $(\mathrm{p}<0,01)$ para híbridos, capacidade geral de combinação (CGC) e capacidade específica de combinação (CEC). Essa significância para ambas as capacidades de combinação evidenciam a importância de ambos os efeitos gênicos aditivos e não aditivos (dominância e ou epistasia) como causas da variação genética observada em todas as características. Tais resultados concordam com as observaçóes de Coimbra et al. (2008), que ressaltam a existência de variabilidade tanto para efeitos gênicos aditivos (CGC) como para não aditivos (CEC). A não significância para CGC x $\mathrm{AMB}$ e CEC x AMB evidência que o controle genético e a seleção de genitores não são específicos em cada ambiente, de forma que os grupos heteróticos utilizados no ambiente de alto $P$ podem ser empregados em ambiente de baixo P.

A julgar pelo valor do quadrado médio, pode-se afirmar que os efeitos de CGC foram mais importantes que os de CEC nesse conjunto de genitores, de forma a realçar a maior contribuição da ação gênica aditiva no controle da resistência à ferrugem polissora. Esses resultados estão de acordo com os obtidos por Silva et al. (2001) que, estudando a capacidade de combinação e os efeitos heteróticos na resistência a $P$. polysora em um grupo de linhagens endogâmicas de milho adaptadas às condiçôes do Brasil Central, observaram maior importância do efeito aditivo que do dominante como fonte de variação para resistência. Brewbaker et al. (2011) também concluíram que, na expressão da resistência à Puccinia polysora, a soma de quadrados da CGC foi superior à da CEC.

Tabela 3. Quadrados médios da análise de variância dialélica entre oito híbridos comerciais de milho e suas 56 combinaçóes híbridas (F1s e recíprocos) para resistência à ferrugem polissora (Puccinia polysora) em função da área abaixo da curva de progresso da doença (AACPD), em dois níveis de adubação fosfatada, em Gurupi, TO, safra 2011/2012

\begin{tabular}{lcc} 
Fonte de variação & Grau de liberdade & Quadrado médio \\
\hline Híbridos & \multicolumn{2}{c}{ Baixo P } \\
\hline CGC & 73 & $5828,18^{\text {ns }}$ \\
\hline CEC & 28 & $8214,50^{\text {ns }}$ \\
\hline ER & 28 & $6224,16^{\text {ns }}$ \\
\hline Híbridos & 63 & $4835,63^{\text {ns }}$ \\
\hline CGC & 7 & Alto P \\
\hline CEC & 28 & $9826,79^{* *}$ \\
\hline ER & 28 & $18991,92^{* *}$ \\
\hline Híbridos & \multicolumn{3}{c}{ Conjunta } \\
\hline CGC & 63 & $8427,10^{*}$ \\
\hline CEC & 7 & $10681,53^{* *}$ \\
\hline ER & 28 & $21533,76^{* *}$ \\
\hline CGC x AMB & 28 & $10956,29^{* *}$ \\
\hline CEC x AMB & 7 & $7693,71^{*}$ \\
\hline
\end{tabular}

ns, *, **: não significativo, significativo a $5 \%$ e significativo a $1 \%$ pelo teste $\mathrm{F}$, respectivamente; Baixo P: $34 \mathrm{~kg} \mathrm{ha}^{-1}$ de $\mathrm{P}_{2} \mathrm{O}_{5}$; Alto P: $170 \mathrm{~kg}_{\text {há }}{ }^{-1}$ de $\mathrm{P}_{2} \mathrm{O}_{5}$
O efeito recíproco (ER) apresentou significância $(\mathrm{p}<0,05)$ em evidência a uma provável influência dos genes citoplasmáticos na expressão do caráter de resistência. Segundo Bordallo et al. (2005), resultados idênticos de um cruzamento e de seu recíproco refletem o controle do caráter por genes nucleares, enquanto resultados diferentes do cruzamento recíproco indicam a contribuição do efeito de origem materna na expressão da característica - o fenótipo dos descendentes é influenciado pelo genitor feminino que contribuiu com o citoplasma. Tal observaçáo difere de resultados apresentados por Silva et al. (2001) e Derera et al. (2008), os quais relataram a não contribuição do efeito recíproco na indução de resistência a doenças fúngicas em plantas de milho.

Em ambiente de alto $\mathrm{P}$ foram observados efeitos significativos $(p<0,05)$ sobre a CGC e CEC. No entanto, em ambiente de baixo P, os efeitos da CGC e CEC sobre o caráter avaliado náo apresentaram significância, evidenciando que, em ambiente estressante, as combinaçóes híbridas não apresentaram, em geral, desvios significativos em relação ao comportamento médio dos genitores. Diversos trabalhos de avaliação da resistência a doenças mostraram que CGC e CEC podem interagir com o ambiente -variaçôes como latitude, temperatura e adubação podem influenciar na expressão do gene de interesse (Engelsing et al., 2011; Nihei e Ferreira, 2012; Silva et al., 2001). Em milho, a deficiência de fósforo, além de comprometer o desempenho de várias funçôes essenciais no metabolismo das células, também influencia a absorção e utilização de outros nutrientes, como o nitrogênio. A redução na disponibilidade de energia (ATP) compromete a absorção ativa de nitrato pelas células radiculares, acarretando um quadro de deficiência nutricional no qual as plantas desenvolvem menor quantidade de tecidos jovens, mais lignificados e menos suscetíveis ao ataque de patógenos (Zambolim e Ventura, 1996). Nesse caso, a deficiência nutricional debilitou os genótipos de tal forma que não se evidenciaram variaçóes significativas da severidade de ataque do patógeno sobre os híbridos.

As estimativas da CGC da área abaixo da curva de progresso da doença (AACPD) a partir da severidade da ferrugem polissora são apresentadas na Figura 1, em que, no eixo das abscissas, estão plotados os valores de CGC procedentes do ambiente com alto $\mathrm{P}$ e, no eixo das coordenadas, representadas as estimativas de CGC oriundas do ambiente de baixo P. Observa-se, nos quadrantes III e IV, a representação dos genótipos que apresentaram estimativas negativas quanto à resistência à ferrugem no ambiente de baixo P. Por se tratar de resistência a doenças, afirma-se que o genótipo, ao apresentar CGC negativa, é potencialmente superior para utilização em programas de melhoramento (Cruz et al., 2012). Dessa forma conclui-se que os genótipos AG 1051, IMPACTO, AG 2040 e P30F80 foram superiores aos demais em ambiente de baixo $\mathrm{P}$, indicando uma possível contribuição deles no aumento da resistência à ferrugem polissora. 
Em ambiente de alto P, comparado a ambiente de baixo P, observou-se um posicionamento semelhante: os genótipos AG 1051, IMPACTO, AG 2040 e BM 2202 (quadrantes I e IV) apresentaram estimativas negativas de CGC sendo, portanto, promissora a sua utilizaçáo como fonte de germoplasma para indução de resistência à ferrugem polissora.

Chama-se a atençáo para o fato de os genitores de destaque quanto a CGC pertencerem a grupos heteróticos diferentes (duro e dentado). De acordo com Borém (2005), a utilização de genitores de grupos heteróticos distintos facilita a exploraçáo da heterose no melhoramento genético, de forma que em programas de seleção recorrente recíproca o melhoramento ocorre simultaneamente em ambas as populaçôes, ampliando a cada ciclo o potencial genético das populaçôes e das linhagens derivadas. Considerando-se a maior contribuição do efeito de genes aditivos na expressão da resistência à ferrugem polissora e que esses genes favoráveis podem ser herdados pelas geraçóes futuras, é possível aumentar

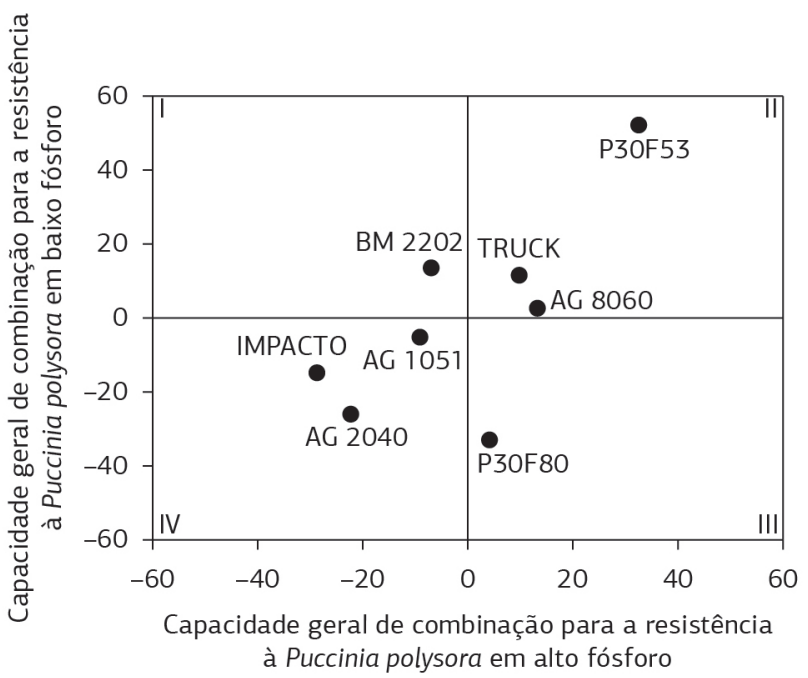

Figura 1. Estimativa do efeito da capacidade geral de combinação de oito híbridos comerciais de milho para resistência à ferrugem polissora (Puccinia polysora) em função da área abaixo da curva de progresso da doença (AACPD), em níveis distintos de adubação fosfatada, em Gurupi, TO, safra 2011/2012. a frequência de alelos de resistência nas populaçóes de cada grupo heteróticos e, por fim, fazer uso da heterose existente para a síntese de híbridos superiores.

O híbrido P30F53 apresentou os maiores efeitos positivos de CGC nos dois ambientes, evidenciando sua maior susceptibilidade a doença, por concentrar um menor número de alelos relacionados à resistência à ferrugem polissora. Tal comportamento já era esperado, uma vez que esse híbrido é caracterizado por sua acentuada susceptibilidade a doenças fúngicas, conforme Dudienas et al. (2009), que ao avaliarem a severidade da ferrugem polissora em 60 híbridos comerciais de diferentes empresas classificaram o P30F53 como o mais susceptível ao patógeno, com média de $25 \%$ de sua área foliar afetada pela doença.

Dentre os oito genitores utilizados na composição dos cruzamentos em dialelo, três contribuíram para o aumento da resistência à ferrugem polissora, simultaneamente, em ambos os ambientes (quadrante IV), caracterizando uma maior frequência de alelos favoráveis à expressão de resistência presentes nesses genitores, quando comparados aos demais. Prova disso é a presença desses genitores nas combinaçóes híbridas que apresentaram valores negativos de CEC, com participaçáo superior a 80\% em ambiente de baixo $\mathrm{P}$ (Tabela 4) e com participação superior a $72 \%$ em ambiente de alto $\mathrm{P}$ (Tabela 5).

Considerando o efeito da CEC da AACPD a partir da severidade da ferrugem polissora, no ambiente de baixo $\mathrm{P}$ foram observadas 25 combinaçôes que apresentaram estimativas negativas, sendo 12 delas combinaçôes recíprocas (Tabela 4). A combinação híbrida recíproca P30F80 x AG 1051 mostrou-se superior para tal condição ambiental, uma vez que apresentou a maior média negativa de CEC $(-61,22)$. Comparando-se ela com a combinação híbrida náo recíproca AG 1051 x P30F80, que apresentou média positiva indesejável à indução de resistência $(2,62)$, pode-se inferir o quanto é significativa a influência dos genes citoplasmáticos (efeito materno) na expressão da característica. Tal comportamento está em concordância com o observado por Guimarães et al. (2009) que, ao avaliarem a capacidade combinatória para resistência à mancha branca em milho,

Tabela 4. Estimativas do efeito da capacidade específica de combinação (CEC) de 28 combinaçôes híbridas (acima da diagonal), e seus recíprocos (abaixo da diagonal), oriundas de dialelo entre oito híbridos comerciais de milho, para resistência à ferrugem polissora (Puccinia polysora), em função da área abaixo da curva de progresso da doença (AACPD), em ambiente de baixa disponibilidade de fósforo, em Gurupi, TO, safra 2011/2012

\begin{tabular}{lrrrrrrrr} 
& AG 2040 & AG 8060 & AG 1051 & BM 2202 & P30F53 & P30F80 & Truck & Impacto \\
AG 2040 & & 46,12 & 101,81 & $-17,96$ & $-26,26$ & $-15,72$ & $-47,73$ & $-20,94$ \\
AG 8060 & $-32,66$ & & $-57,85$ & 9,19 & 7,62 & 30,09 & 0,21 & $-23,00$ \\
\hline AG 1051 & 45,56 & 15,81 & & $-7,77$ & $-53,61$ & 2,92 & 7,57 & 6,91 \\
\hline BM 2202 & $-37,63$ & $-42,41$ & 0,07 & & 0,01 & $-30,54$ & 71,91 & 9,44 \\
\hline P30F53 & $-48,04$ & $-2,49$ & 2,47 & 50,07 & & $-6,26$ & 64,03 & 28,91 \\
\hline P30F80 & 2,54 & $-6,66$ & $-61,22$ & $-13,34$ & 0,40 & & 16,48 & $-1,16$ \\
\hline Truck & 3,34 & $-58,11$ & 22,53 & 16,58 & 13,34 & 44,33 & & $-15,95$ \\
Impacto & $-2,02$ & 1,85 & 2,05 & $-28,54$ & 93,39 & 45,5 & $-0,01$ & \\
\hline
\end{tabular}


Tabela 5. Estimativas do efeito da capacidade específica de combinação (CEC) de 28 combinaçóes híbridas (acima da diagonal), e seus recíprocos (abaixo da diagonal), oriundas de dialelo entre oito híbridos comerciais de milho, para resistência à ferrugem polissora (Puccinia polysora), em função da área abaixo da curva de progresso da doença (AACPD), em ambiente de alta disponibilidade de fósforo, em Gurupi, TO, safra 2011/2012

\begin{tabular}{lrrrrrrrrr} 
& AG 2040 & AG 8060 & AG 1051 & BM 2202 & P30F53 & P30F80 & Truck & Impacto \\
AG 2040 & & 66,47 & $-29,18$ & $-6,87$ & $-43,73$ & 21,93 & $-27,41$ & 64,51 \\
\hline AG 8060 & 17,00 & & $-23,84$ & $-40,88$ & 31,19 & $-17,12$ & $-28,18$ & 3,41 \\
\hline AG 1051 & 20,35 & 46,87 & & $-2,13$ & $-49,81$ & 35,64 & 47,15 & 58,98 \\
BM 2202 & $-31,70$ & 4,67 & 26,34 & & $-3,19$ & $-12,47$ & 102,77 & $-3,87$ \\
P30F53 & $-5,61$ & 104,49 & 64,10 & 15,33 & & $-31,22$ & 30,43 & $-10,85$ \\
P30F80 & 6,31 & 20,62 & 18,08 & $-22,76$ & 10,31 & & 45,70 & 7,26 \\
\hline Truck & $-6,77$ & $-27,34$ & $-1,76$ & $-93,93$ & 72,68 & 0,63 & & $-49,92$ \\
Impacto & 19,36 & 56,36 & $-76,84$ & $-92,23$ & 63,71 & 27,72 & 4,00 & \\
\hline
\end{tabular}

relataram a contribuição do efeito materno na obtenção de indivíduos superiores.

Inversamente, o cruzamento AG 1051 x AG 2040, ao apresentar o maior valor positivo de CEC em baixo P $(101,81)$, promoveu o aumento da susceptibilidade do híbrido à incidência da doença. Tal fenômeno pode estar relacionado ao fato de os genitores, por serem híbridos da mesma empresa comercial, possuírem base genética estreita, reduzindo a heterose quando cruzados entre si, com aumento na frequência de alelos deletérios e a inexpressão do caráter de interesse.

$\mathrm{Na}$ determinação do efeito da CEC no ambiente de alto $P$ foi possível identificar 25 combinações híbridas com estimativas negativas, de intensidade média $13 \%$ superior à apresentada em ambiente de baixo P. Apesar de a interação CEC x AMB não ser significativa, esse comprova uma maior dissimilaridade genética dos genitores em ambiente de alto $\mathrm{P}$, muito em virtude da perca alélica governada em baixo $\mathrm{P}$ a partir do surgimento de cultivares modernas direcionadas ao cultivo em condiçôes ótimas de adubação fosfatada. Também foi verificada a menor participação dos híbridos recíprocos nas hibridaçóes com estimativas negativas, ao constituírem apenas nove combinaçóes híbridas superiores (Tabela 5). Contudo, da mesma forma que em ambiente de baixo $\mathrm{P}$, a combinação híbrida de maior estimativa negativa foi composta por um cruzamento recíproco (TRUCK x BM 2202). Essa tendência observada no trabalho demonstra que há diferença significativa na escolha do genitor feminino para realização de hibridações voltadas à obtenção de resistência à ferrugem polissora. A escolha correta e criteriosa do genitor feminino é um aspecto importante, nela deve ser levada em consideração a herança extracromossômica responsável pela expressão do caráter em milho.

\section{CONCLUSÃO}

Os efeitos da CGC são mais importantes do que os da CEC nesse conjunto de genitores, o que demonstra a predominância de alelos de efeito aditivo na expressão de resistência à ferrugem polissora.
Há um efeito materno pronunciado para resistência à ferrugem polissora, o qual deve ser considerado na seleção dos genitores femininos para hibridaçóes.

A CGC indica que os genitores AG 1051, AG 2040 e IMPACTO são promissores no aumento da resistência à ferrugem polissora.

A CEC indica que a hibridação envolvendo os genitores P30F80 x AG 1051 promove aumento na resistência à ferrugem polissora em ambiente de baixo $\mathrm{P}$, e que a hibridação envolvendo os genitores TRUCK x BM 2202 promove aumento na resistência à ferrugem polissora em ambiente de alto $\mathrm{P}$.

\section{REFERÊNCIAS}

AGROCERES. Guia Agroceres de Sanidade. 2. ed. São Paulo: Sementes Agroceres, 1996. 72p.

BRASIL. Ministério da Agricultura, Pecuária e Abastecimento - MAPA. Zoneamento agrícola de risco climático - Cultura do milho. Brasília, 2013. Disponível em: <http://www.in.gov.br/visualiza/index. jsp? data $=11 / 07 / 2013 \&$ jornal $=1 \&$ pagina $=20 \&$ total $A r q u i v o s=352>$. Acesso em: 19 out. 2013.

BREWBAKER, J.L.; KIM, S.K.; SO, Y.S.; LOGRONO, M. MOON, H.G.; MONG, R. G.; LU, X.W.; JOSUE, A.D. General resistance in maize to Southern Rust (Puccinia polysora Underw.). Crop Science, v.51, p.1393-1409, 2011. http://dx.doi.org/10.2135/cropsci2010.06.0327

BORDALLO, P.N.; PEREIRA, M.G.; AMARAL JÚNIOR, A.T.; GABRIEL, A.P.C. Análise dialélica de genótipos de milho doce e comum para caracteres agronômicos e proteína total. Horticultura Brasileira, v.23, p.123-127, 2005. http://dx.doi.org/10.1590/ S0102- 05362005000100026

BORÉM, A. Melhoramento de espécies cultivadas. 2. ed. Viçosa: Ed. UFV, 2005. 969p.

CARVALHO, E.V.; AFFÉRRI, F.S.; DOTTO, M.A.; PELUZIO, J.M. Avaliação da resistência horizontal de híbridos de milho à mancha parda, no Estado do Tocantins - Brasil. Revista Verde de Agroecologia e Desenvolvimento Sustentável, v.5, p.170-178, 2010.

COIMBRA, R.R.; MARTINS, E.C.A.; MIRANDA, G.V.; NAOE, L.K.; CARDOSO, E.A.; ARCHANGELO, E.R. Capacidade de 
combinação de genótipos de milho para solos com baixos níveis de fertilidade. Revista de Ciências Agrárias, v.50, p.23-34, 2008.

COSTA, D.F.; VIEIRA, B.S.; LOPES, E.A.; MOREIRA, L.C.B. Aplicaçáo de fungicidas no controle de doenças foliares na cultura do milho. Revista Brasileira de Milho e Sorgo, v.11, p.98-105, 2012.

CRUZ, C.D. Programa GENES: aplicativo computacional em genética e estatística versão Windows. Viçosa: UFV, 2006. 442p.

CRUZ, C.D.; REGAZZI, A.J.; CARNEIRO, P.C. Métodos biométricos aplicados ao melhoramento genético. 4. ed. Viçosa: UFV, 2012, 512p.

DAS, M.K. Inheritance of slow-rusting resistance to leaf rust in wheat. Crop Science, v.32, p.1452-1456, 1992. http://dx.doi.org/10.2135/ cropsci1992.0011183X003200 060028x

DERERA, J.; TONGOONA, P.; PIXLEY, K.V.; VIVEK, B.; LAING, M.D.; VAN RIJ, N.C. Gene action controlling gray leaf spot resistance in Southern African mayze germplasm. Crop Science, v.48, p.93-98, 2008. http://dx.doi.org/10.2135/cropsci2007.04.0185

DUDIENAS, C.; DUARTE, A.; SAWAZAKI, E.; TICELLI, M.; GALLO, P.B.; LEÃO, P.C.; HOFFMANN, H.P. Doenças da cultura do milho na regiáo Centro Norte no Estado de São Paulo, na safra 2008/2009. Nucleus, v.1, p.1-11, 2009. http://dx.doi. org/10.3738/1982.2278.291

ELLIS, M.B. Dematiaceous Hyphomycetes. Surrey: Commonwealth Mycological Institute, 1971. 607p.

ENGELSING, M.J., ROZZETTO, D.S., COIMBRA, J.L.M., ZANIN, C.G., GUIDOLIN, A.F. Capacidade de combinação em milho para resistência a Cercospora zeae-maydis. Revista Ciência Agronômica, v.42, p.232-241, 2011. http://dx.doi.org/10.1590/ S1806-66902011000100029

GRIFFING, B. Concept of general and specific combining ability in relation to diallel crossing systems. Australian Journal Biology Science. v.9, p.463-493, 1956. http://dx.doi.org/10.1071/BI9560463

GUIMARĀES, P.S.; PATERNIANI, M.E.A.G.Z.; DUDIENAS, C.; LÜDERS, R.R.; GALLO, P.B. Capacidade combinatória para resistência à mancha branca em linhagens endogâmicas de milho. Summa phytopathol, v.35, p.282-287, 2009. http://dx.doi.org/10.1590/ S0100-54052009000400005
JOSÉ, S.C.B.R.; PINHO, E.V. R.; PINHO, R.G.; RAMALHO, M.A.P.; SILVA FILHO, J.L. Controle genético da tolerância à alta temperatura de secagem em sementes de milho. Revista Brasileira de Milho e Sorgo, v.3, p.414-428, 2004.

NIHEI, T.H.; FERREIRA, J.M. Análise dialélica de linhagens de milho com ênfase na resistência a doenças foliares. Pesquisa Agropecuária Brasileira, v.47, p.369-377, 2012. http://dx.doi.org/10.1590/S0100204X2012000300008

SCAPIM, C.A.; CARVALHO, C.G.P.; CRUZ, C.D. Uma proposta de classificação dos coeficientes de variação para a cultura do milho. Pesquisa Agropecuária Brasileira, v.30, p.683-686, 1995.

SILVA, H.P.; BARBOSA, M.P.M.; NASS, L.L.; CAMARGO, L.E.A. Capacidade de combinaçáo e heterose para resistência a Puccinia polysora Underw. em milho. Scientia Agricola, v.58, p.777-783, 2001. http://dx.doi.org/10.1590/S0103-90162001000400020

SILVEIRA, F.T.; JUNQUEIRA, B.G.; SILVA, P.C.; MORO, J.R. Comportamento de linhagens elites de milho para resistência aos enfezamentos. Revista Brasileira de Milho e Sorgo, v.5, p.431-442, 2006.

VAZ-DE-MELO, A.; AFFÉRRI, F.S.; PELUZIO, J.M.; SANTOS, G.R.; CARVALHO, E.V. Reação de híbridos de milho à curvularia ssp, sob dois níveis de adubaçáo com nitrogênio, no sul do Tocantins. Scientia Agraria, v.11, p.149-154, 2010.

VIEIRA, R.A.; SCAPIM, C.A.; TESSMANN, D.J.; HATA, F.T. Análise dialélica da produtividade, capacidade de expansão e resistência à ferrugem-polissora em linhagens de milho-pipoca. Revista Ciência Agronômica, v.42, p.774-780, 2011. http://dx.doi.org/10.1590/ S1806-66902011000300025

VIVEK, B.; ODONGO, O.; NJUGUNA, J.; IMANYWOHA, J.; BIGIRWA, G.; DIALLO, A.; PIXLEY, K. Diallel analysis of grain yield and resistance to seven diseases of African maize (Zea mays L.) inbred lines. Euphytica, v.172, p.329-340, 2010. http://dx.doi. org/10.1007/s10681-009-9993-5

ZAMBOLIM, L.; VENTURA, J.A. Resistência a doenças induzidas pela nutrição mineral das plantas. Informaçóes Agronômicas, v.75, p.1-16, 1996. 